\title{
Os donos do Mar(anhão): herança política e poder local em um Estado brasileiro
}

\section{Elthon Ranyere Oliveira Aragão'}

\begin{abstract}
RESUMO: Fruto de parte de tese de doutorado, o trabalho aborda diferentes dimensões de poder da família Sarney no Maranhão ao longo de meio século. Após ser eleito governador do Maranhão em 1965, José Sarney inicia um período chamado na literatura política local de sarneysísmo, no qual uma família deteve as mais privilegiadas posições de poder não apenas político, mas também em diferentes áreas sociais. Para tanto, alguns parentes foram fundamentais para a continuidade do processo, que se inicia por volta da década de 1950, com seu pai, o desembargador Araújo Costa. Dos três filhos de José Sarney, dois aventuram-se na esfera política, sendo Sarney Filho deputado federal por nove mandatos consecutivos e a filha, Roseana Sarney, eleita para os cargos de deputada federal, governadora do Maranhão e senadora da república. Atualmente, Adriano Sarney, neto do ex-presidente, é deputado estadual no Maranhão. Seu outro filho, Fernando Sarney, é o principal acionista do maior grupo de comunicação do estado, além de vice-presidente da região norte da Confederação Brasileira de Futebol. Outras áreas sociais também contam com componentes da família Sarney, como o judiciário, onde alguns indivíduos são juízes e, atualmente, Nelma Sarney é desembargadora do Tribunal de Justiça. Espraiando o poder por diversas esferas sociais, a família Sarney consegue o controle quase absoluto de um estado da federal por meio século, sempre tendo seus membros como artífices do processo de dominação.
\end{abstract}

Palavras-chave: Família Sarney. Maranhão. Poder local.

\section{The owners of the Mar (anhão): political inheritance and local power in a Brazilian State}

\begin{abstract}
As a result of a doctoral thesis, the paper approaches different dimensions of power of the Sarney family in Maranhão during half a century. After being elected Governor of Maranhão in 1965, José Sarney began a period called in the local political literature of Sarneyism, in which a family detained the most privileged positions of power not only political, but also in different social areas. To that end, some relatives were fundamental for the continuity of the process, which began around the 1950s, with his father, the judge Araújo Costa. Sarney Filho was a federal deputy for nine consecutive terms and his daughter, Roseana Sarney, was elected to the positions of federal deputy, governor of Maranhão and senator of the republic. Currently, Adriano Sarney, grandson of the former president, is a state deputy in Maranhão. His other son, Fernando Sarney, is the main shareholder of the state's largest communications group, as well as vice president of the northern region of the Brazilian Football Confederation. Other social areas also have components of the Sarney family, such as the judiciary, where some individuals are judges, and currently Nelma Sarney is the adjudicator of the Court of Justice. Spraying power across diverse social spheres, the Sarney family gains almost absolute control of a federal state for half a century, always having its members as architects of the domination process.
\end{abstract}

Keywords: Sarney family. Maranhão. Local power.

- Enviado em 01/05/2017

- Aprovado em 17/05/2017

\begin{abstract}
${ }^{1}$ Graduado em História e Jornalismo, ambos pela Universidade Federal do Maranhão. Mestre em Ciências Sociais pela Universidade Federal do Maranhão. Doutor em Sociologia pela Universidade Federal de Sergipe. Professor dos cursos de Jornalismo e Publicidade e propaganda da Faculdade Estácio de São Luís. Uma versão preliminar desse texto foi apresentada no VIII Seminário Nacional de Sociologia e Política realizado de 17 a 19 de maio de 2017 na UFPR. E-mail: E-mail: elthonaragao@gmail.com
\end{abstract}




\section{INTRODUÇÃO}

O presente artigo estuda as trajetórias sociais e políticas dos membros da família Sarney no Maranhão desde a década de 1960 até o presente momento. José Sarney, figura conhecida da política brasileira mantém fortes relações com a política maranhense, sendo sua família a detentora de diversas postos de comando, sejam eles no poder executivo, legislativo ou judiciário. O texto em questão focará em duas, excetuando o último citado. Para a confecção do trabalho, adota-se aqui conceitos e métodos usados pela sociologia política, destacando estudo de elites, sendo o mesmo primordial para entender as (re)configurações da política local nos últimos cinquenta anos. Algumas variáveis foram excluídas, como as relações com níveis mais baixos (os municípios) e mais altos (a esfera federal), bem como o judiciário. Ambos os temas serão pontos de investigação em trabalhos vindouros, que, juntamente com o presente, tentarão entender de forma mais ampla as relações da família Sarney nos mais diversos espaços e esferas sociais.

\section{O "SARNEYSMO" E A CONDIÇÃO COMO UM LÍDER DE EXPRESSÃO NACIONAL: DE GOVERNADOR A PRESIDENTE}

Analisemos, pois, como o filho de um desembargador, natural de uma cidade do interior do estado do Maranhão, construiu sua história política, passando de deputado federal em 1958 até chegar a presidência da república no ano de 1985.

Nascido em 1930 na cidade de Pinheiro, localizada na Baixada Maranhense, José de Ribamar Ferreira de Araújo Costa, mais conhecidos como José Sarney, com 20 anos de idade ingressou na Faculdade de Direito, e formou-se bacharel em 1954. Filho de desembargador, fez seus estudos no Liceu Maranhense e na Faculdade de Direito do Maranhão. A introdução de José Sarney na esfera política se deu através da rede de relações de seu pai que, muito influente, amigo de longa data do senador Vitorino Freire, no início dos anos de 1950, solicitou a este que intercedesse junto a Eugenio Barros, governador do Maranhão à época, uma ocupação para José 
Sarney dentro dos quadros do governo. Desta feita o jovem promissor assume o cargo de assessor direto do governador. (FREIRE, 1978, p. 273-274).

Na política, exerceu os cargos de deputado federal por três mandatos (de 1954 a 1965), governador do estado entre 1966 e 1970, senador pelo Maranhão entre os anos de 1970 e 1974 e pelo Amapá entre 1991 e 2014, presidente da república na segunda metade da década de 1980, assumindo quando o cabeça de chapa falece após problemas de saúde (Sarney foi eleito para o cargo de vice-presidente). Durante sua trajetória política foi filiado ao Partido Social Democrático (PSD), União Democrática Nacional (UDN), Aliança Renovadora Nacional (ARENA), Partido Democrático Social (PDS) e Partido do Movimento Democrático Brasileiro (PMDB), onde está filiado desde a década de 1980.

Concomitante à atividade política, participou de movimentos culturais na cidade em São Luís, ao mesmo tempo produzia seus primeiros escritos literários, o que the rendeu o ingresso na Academia Maranhense de Letras (AML) aos 23 anos. É membro do Instituto Histórico e Geográfico do Maranhão (IHGM), Academia Maranhense de Letras (AML) e Academia Brasileira de Letras (ABL). É autor de diversos livros, como Norte das Águas, Marimbondos de fogo e $O$ dono do mar ${ }^{2}$.

A sua atuação nos bastidores da política associada à produção literária, possibilitou frequente contato com várias figuras políticas, obtendo prestigio, o que lhe levou a investir na candidatura a deputado federal, pelo PSD de Vitorino Freire, no pleito de 1954, não obtendo margem necessária de votos para ocupar a cadeira, mas ainda assim conseguiu a suplência e assumiu a legislatura em algumas oportunidades. Não permaneceu muito tempo naquele partido, pois um desentendimento interno provocou (Vitorino Freire queria trazer Assis Chateaubriand da Paraíba para concorrer ao senado pelo Maranhão) uma dissidência dentro do partido. Encabeçada por José Sarney e Renato Archer, tal dissidência "pulou o muro, aliando-se às forças de oposição que desde tempos lutava contra o vitorinismo" (BUZAR, 2014, p. 286).

Nesta época, o Maranhão era controlado politicamente pelo senador Vitorino Freire. Pernambucano de nascimento (Arcoverde), filho de trabalhadores rurais, fez os primeiros estudos no interior de Pernambuco, indo a Recife para fazer curso superior ${ }^{3}$. Antes de adentrar a esfera política, foi funcionário público federal. Chegou ao Maranhão em 1933 por ocasião da nomeação

\footnotetext{
2 No total, José Sarney tem vinte e quatro obras publicadas.

${ }^{3}$ Os textos sobre Vitorino Freire não indicam qual curso foi feito pelo político.
} 
dos interventores estaduais pelo presidente em exercício Getúlio Vargas, ocupando o cargo de secretário-geral do Maranhão, a convite do interventor Martins de Almeida. Tentou eleger-se deputado federal, mas, fracassando, migrou para o Rio de Janeiro, onde oficial de gabinete no Ministério da Viação e Obras Públicas. Retornou ao Maranhão após a queda de Vargas, reestruturou o PSD maranhense e, nas eleições de 1945, foi eleito deputado federal. Na sequência desse mandato, obteve a legislatura de Senador. A partir daí Vitorino Freire passou a exercer a hegemonia sobre a política maranhense, sempre articulando a candidatura e eleição dos governadores ligados a ele ${ }^{4}$.

José Sarney entrou para vida pública apadrinhado por Vitorino Freire, fez parte do PSD, onde construiu suas bases políticas num curto espaço de tempo. Em 1955, se desvinculou do PSD e juntamente com outros deputados dissidentes se integrou a UDN. Naquela agremiação fez parte da chamada "Bossa Nova" que "levou-o a aproximar-se das posições reformistas e nacionalistas, chegando a compor a Frente Parlamentar Nacionalista, movimento político suprapartidário que buscava aprovar no Congresso Nacional os projetos de Reformas de Base" (COSTA, 2006, p. 75)

A sua ascensão política começa de fato em 1958, quando aos 28 anos de idade foi eleito deputado federal pela UDN e partícipe das Oposições Coligadas (Partido Social Progressista - PSP; UDN; Partido da República - PR; e Partido Democrata Cristão - PDC) união política formada pelos oposicionistas para superar o grupo "vitorinista" nas eleições. Dois anos depois a UDN se desligou da frente oposicionista para apoiar a candidatura de Newton Belo do PSD que foi eleito governador em 1960. Em troca, a UDN barganhou vários cargos públicos no governo do estado: “Este posicionamento custou ao partido e, em especial, ao seu presidente estadual (José Sarney) as mais severas críticas por parte dos demais segmentos oposicionistas, que consideraram o acordo PSD/UDN espúrio" (COSTA, 2006, p. 75)

A escolha de Sarney pela UDN foi decisiva. Nas eleições presidenciais de 1960 o candidato eleito Jânio Quadros do Partido Trabalhista Nacional (PTN), havia obtido a adesão do PDC, PR, PL e por fim a UDN. Com o início do mandato presidencial, José Sarney passou a ter mais visibilidade na esfera nacional ao se tornar vice-líder do governo e porta-voz do governo Newton Bello (19611965) junto ao palácio do Planalto. O próprio opositor Vitorino Freire reconheceria anos depois as

\footnotetext{
${ }^{4}$ Teve um filho, Luís Freire, que foi deputado estadual entre 1963 e 1966. Candidatou-se a senador pelo Maranhão em 1982, mas não teve êxito, ficando na primeira suplência. Dentre os cargos que ocupou na administração pública, destaca-se sua nomeação para o Tribunal de Contas da União.
} 
estratégias de José Sarney: “Eleito deputado, Sarney soube fortalecer-se politicamente. Vaidoso e oportunista sabia esperar para ver de que lado estava soprando o vento, a fim de assumir posições que Ihe fossem favoráveis" (FREIRE; 1978, p. 274). Assume o cargo de governador do Maranhão em 1966 adotando um discurso renovador, do novo ${ }^{5}$, o que viria a ser seu projeto governamental: “Um produto político chamado 'Maranhão Novo' pretende fazer do proclamado 'desenvolvimento' do Maranhão, um elemento que permita não o regresso temporal, mas o estado de consagração que é dado pela prosperidade passada" (GONÇALVES, 2000, p. 108).

\section{CONSAGRANDO OS FILHOS: SARNEY FILHO E ROSEANA SARNEY}

José Sarney comanda o que se costuma chamar "oligarquia Sarney" ${ }^{6}$. Na literatura política maranhense ${ }^{7}$, o conceito pouco é discutido, sendo empregado de forma corriqueira sem aprofundamento, bem como "coronel", palavra frequentemente usada para se referir a José Sarney.

Com relação ao uso do termo oligarquia especificamente sobre o caso do Maranhão, publicação recente discorre sobre os usos que são feitas da mesma, bem como a confecção de nomes para classificar as diferentes "oligarquias" que já existiram no estado. Em "Ismos", "ícones" e intérpretes: as lógicas das "etiquetagens" na política de dois estados brasileiros - MA e RS (2012), Igor Grill destaca que termos como "sarneysismo" e "vitorinismo" (para citar as duas

\footnotetext{
${ }^{5}$ Wagner Cabral (1997) analisa a questão do discurso do "novo" nos governos que envolvem José Sarney e seus aliados a partir da década de 1970 (1997).

"O termo "coronelismo" foi e é amplamente debatido nas discussões sobre poder local, tendo como base os textos de Victor Nunes Leal (1997), Maria Isaura de Queiroz (1969) e José Murilo de Carvalho (1997). O mesmo é definido como um sistema de troca de favores entre os níveis federal, estadual e municipal. Nas palavras de Carvalho, "o coronelismo é, então, um sistema político nacional, baseado em barganhas entre o governo e os coronéis. O governo estadual garante, para baixo, o poder do coronel sobre seus dependentes e seus rivais, sobretudo cedendo-lhe o controle dos cargos públicos, desde o delegado de polícia até a professora primária. O coronel hipoteca seu apoio ao governo, sobretudo na forma de votos. Para cima, os governadores dão seu apoio ao presidente da República em troca do reconhecimento deste de seu domínio no estado" (1997). Nesse sistema, havia tensão em todos os níveis, diferente que se possa imaginar que tudo funcionaria de forma harmônica. $O$ jogo político é feito de disputas e elas acontecem constantemente. Entretanto, é importante percebe o papel do coronel como um mediador, sendo a ponte entre aqueles que não têm acesso a determinados recursos e o próprio bem, independentemente de sua natureza, seja algo material como alimentos, seja a ajuda a conseguir um leito de hospital ou mesmo a alocação de um indivíduo em um emprego. Porém, Leal ressalta que o coronelismo não está assentado na força do coronel, mas sim na fraqueza do mesmo e na das pessoas que dele dependem.

7 Dentre os principais autores que trabalham questões políticas no Maranhão, cita-se COSTA (2006), GONÇALVES (2000; 2008), COUTO (2009), BORGES (2005), PACHÊCO FILHO (2001).
} 
"oligarquias" mais faladas no caso maranhense) são construções que, antes de significar uma unidade em torno de um político, serve para localizar um período de controle das ações por parte de um determinado político e classificar personagens enquanto participantes de diferentes "lados" dos jogos. Afirma ainda que tais classificações só fazem sentido se pensadas com relação a outras, numa relação de interdependência: “a força da expressão 'vitorinismo' adveio das estratégias bem sucedidas dos seus opositores, visando estabelecer uma descontinuidade entre o 'período' da política maranhense dominado por Victorino Freire e aquele iniciado com a chegada das 'oposições coligadas' ao governo do estado, quando, em 1965, José Sarney elegeu-se Governador" (GRILL, 2012, p. 198) e complementa sobre o "sarneysismo": "Assim como ocorreu com o termo 'vitorinismo', sua utilização e fixação no espaço político dependeram simultaneamente e diretamente do significado atribuído por seus oponentes e seu uso como instrumento de estigmatização de protagonistas vinculados a José Sarney pessoal e politicamente" (p. 202). Dessa forma, segundo Grill, "vitorinismo" e "sarneysismo" viram sinônimos de "oligarquia" e que essa etiquetagem é usada para estigmatizar aqueles que fazem parte dela ${ }^{8}$, sendo ela plástica e flexível. Assevera ainda que "o uso desses termos aponta uma tendência de transferir a explicação dos fenômenos políticos às decisões, vontades, interesses e desígnios de uma coletividade substancializada ('a oligarquia' ou 'o sarneyismo'), adotando o modelo reificante de perceber a 'vida social', em detrimento do relacional ou processual" (p. 205). A obra do jornalista Benedito Buzar, Vitorinistas e oposicionistas: biografias (2001) é um exemplo do que fala Grill, uma vez que há uma clara classificação de político, alguns sendo colocados como partidários de Vitorino Freire e aqueles que eram contrários a ele.

De todos os governadores do Maranhão após ter saído do cargo, o único que não era ligado a José Sarney foi Osvaldo da Costa Nunes Freire. O mesmo tinha fortes vínculos com Vitorino Freire. Convém destacar que esse último ainda tinha força política no estado e na esfera federal. Tanto ele como José Sarney indicaram nomes para o cargo de governador do Maranhão em 1978, sendo Nunes Freire o nome que mais se aproximou do consenso. Entretanto, o então governador não esteve sob influência do à época senador da república como os outros. A década

\footnotetext{
8 De forma mais tímida, Gonçalves (2008) faz referência aos usos do termo "oligarquia": “Essa noção de 'oligarquia' serve ao discurso de desqualificar os procedimentos de uma gestão governamental, independentemente de quem seja o chamado 'oligarca'. Está presente nos discursos de José Sarney para desqualificar s inimigos políticos, como se fez em relação a Vitorino Freire, e está presente nos discursos dos seus inimigos políticos, que acionam a categoria para atribuir a construção da chamada 'oligarquia Sarney' ao próprio José Sarney” (p. 69).
} 
de 1970, nesse sentido, é sintomática no sentido de ser um período de transição política. Era o começo do fortalecimento político de José Sarney enquanto principal liderança local, que se solidificou com sua ida para a presidência da república na década de 1980, ainda que pese o apoio para Epitácio Cafeteira ao governo do Maranhão em 1986 ter sido alinhavado pelo PMDB nacional, uma vez que o mesmo era adversário político de José Sarney no momento ${ }^{9}$. A seguinte, 1990, foi o decênio mais tranquilo no que diz respeito ao domínio político de José Sarney sobre o Maranhão.

Se os governadores eram indicados e/ou apoiados por José Sarney, alguns deles romperam com o chefe político local durante o mandato ou ao término do mesmo. Nesse caso, encontram-se João Castelo, Luiz Rocha, Epitácio Cafeeira e José Reinaldo Tavares. Membros da família Sarney ou alguém apoiado por eles perdem eleições em apenas duas ocasiões, quando Roseana Sarney perde o pleito ${ }^{10}$ e na última, quando Edison Lobão Filho, filho do ex-governador Edison Lobão, derrotado pelo atual governador do estado, Flávio Dino. Ao estendermos a análise para os deputados (estaduais e federais) e senadores, percebe-se que o poder de atração que a família Sarney exerce sobre os personagens políticos do estado é muito grande. A tabela a seguir explicita a quantidade de deputados e senadores eleitos no Maranhão pós-1970, situando os mesmos enquanto situação ou oposição, ou seja, se faziam parte da coligação dos atuais governadores à época. Para efeito demonstrativo, "situação" refere-se aos aliados da família Sarney, independente se estavam com o apoio do governador à época ou não. Tal situação aconteceu apenas no ano de 2006.

\footnotetext{
${ }^{9}$ Epitácio Cafeteira esteve alinhado com a família Sarney em diversos momentos de sua trajetória política, bem como distante da mesma em outros. Atualmente, é senador da república após ter sido um dos candidatos apoiados pelos Sarney em 2010, quando duas vagas estavam disponíveis para o Maranhão.

${ }^{10}$ Após dois anos de mandatos, Jackson Lago perde o mandato ter sido considerado culpado da acusação de compra de votos durante a campanha. A chapa é anulada e Roseana Sarney assume o posto de governadora pela terceira vez.
} 
Tabela 01: Deputados estaduais, federais ${ }^{11}$ e senadores eleitos pelo Maranhão

\begin{tabular}{|c|c|c|c|c|c|c|}
\hline \multirow{2}{*}{$\begin{array}{c}\text { Eleição/ } \\
\text { Forças } \\
\text { políticas/C } \\
\text { argos }\end{array}$} & \multicolumn{2}{|c|}{ Dep. Estadual } & \multicolumn{2}{c|}{ Dep. Federal } & \multicolumn{2}{c|}{ Senador } \\
\cline { 2 - 7 } & Situação & Oposição & Situação & Oposição & Situação & Oposição \\
\hline 1970 & 17 & 4 & 6 & 1 & 2 & 0 \\
\hline 1974 & 22 & 5 & 8 & 1 & 1 & 0 \\
\hline 1978 & 31 & 5 & 10 & 2 & 2 & 0 \\
\hline 1982 & 33 & 8 & 14 & 3 & 1 & 0 \\
\hline 1986 & 34 & 8 & 16 & 2 & 2 & 0 \\
\hline 1990 & 35 & 7 & 16 & 2 & 1 & 0 \\
\hline 1994 & 31 & 11 & 15 & 3 & 2 & 0 \\
\hline 1998 & 30 & 12 & 13 & 5 & 1 & 0 \\
\hline 2002 & 24 & 18 & 9 & 9 & 2 & 0 \\
\hline 2006 & 17 & 25 & 7 & 11 & 1 & 0 \\
\hline 2010 & 29 & 13 & 13 & 5 & 2 & 0 \\
\hline 2014 & 29 & 13 & 12 & 6 & 0 & 1 \\
\hline
\end{tabular}

Fonte: TSE

A eleição de 2006 é sui generis, pois foi a primeira vez desde a redemocratização do Brasil em que um candidato apoiado pela família Sarney foi derrotado. Nesta eleição, o governador do estado era José Reinaldo Tavares, que apoiou Jackson Lago, vencedor da eleição. A tabela acima expõe o grande número de deputados (tanto estaduais como federais) eleitos com o apoio do então governador. Foi a única vez em que o número de deputados eleitos com o apoio da família Sarney foi menor que os adversários. O grande número pode ser explicado por uma forte migração partidária que aconteceu após o rompimento citado. Segundo Grill (2010) o PDT foi o partido que mais recebeu filiado entre 2006 e 2009, quando acontece a cassação de Jackson Lago.

11 Para conhecer com mais detalhes um perfil dos deputados federais maranhenses, consultar Grill (2008), onde o autor traça um quadro sociográfico dos representantes maranhenses na Câmara dos deputados entre os anos de 1945 e 2006, levando em conta variáveis como grau de escolarização, profissão, carreiras políticas, entre outras. 
Parte de toda a estrutura que se convencionou chamar "oligarquia Sarney" passa pelos filhos. Dos três, dois fazem parte diretamente do universo da política. O terceiro é empresário e comanda o sistema de comunicação da família. José Sarney Filho participa da vida política desde o final da década de 1970. Roseana Sarney adentra o universo político no início da década de 1990. Filho mais novo de José Sarney, Sarney Filho é que o primeiro adentra a esfera política, ao concorrer e vencer a disputa para deputado estadual em 1978, quando tinha vinte e um anos de idade. Pelo que foi possível pesquisar, não atuou em cargos na administração pública antes de se aventurar na política. É formado ${ }^{12}$ em Direito pela Universidade Federal do Maranhão e tem como trajetória partidária filiações na ARENA, PDS, PFL e Partido Verde (PV). Sua filiação nos dois primeiros coincide com o período em que seu pai também era filiado naqueles partidos. A mudança se dá em meados da década de 1980, quando ingressa no PFL e quase vinte anos depois quando vai para o Partido Verde, onde é filiado atualmente.

Após sua primeira vitória em pleitos, candidatou-se apenas para um cargo, o de deputado federal, sendo eleito em todas as oportunidades desde a eleição de 1982. São nove eleições para a Câmara dos Deputados de forma consecutiva. Durante esse período, assumiu os cargos de Secretário para Assuntos Políticos do Estado do Maranhão entre os anos de 1988 e 1990 no governo de Epitácio Cafeteira e Ministro de Estado do Meio Ambiente entre 1999 e 2002, durante o segundo mandato de Fernando Henrique Cardoso como presidente da república. Mesmo sendo mais novo que sua irmã, Sarney Filho inicia sua participação nos jogos políticos mais cedo que ela, ainda no final da década de 1970. Durante toda a sua trajetória política, em apenas um momento o mesmo é cogitado a concorrer a outro cargo. Em 1990, teve seu nome envolvido na disputa para o governo estadual, porém, abriu mão da candidatura por não ter o apoio do então governador Epitácio Cafeteira. Mesmo que seja levantada a opção que a desistência tenha sido por conta da não aceitação de seu nome junto ao eleitorado (GONÇALVES, 2008, p. 112), a hipótese mais provável é que o rompimento do então governador tenha levado Sarney Filho a abrir em face à candidatura de Edison Lobão ${ }^{13}$ :

\footnotetext{
${ }^{12}$ Iniciou o curso de Economia na Pontifícia Universidade Católica (PUC) de São Paulo, mas não concluiu a graduação.

${ }^{13}$ Ressalte-se que, desde a ascensão de José Sarney ao cargo de governador em 1966, apenas em 2014 um candidato pelo então governador do estado perdeu uma eleição. Jackson Lago, quando derrota Roseana Sarney em 2006 era apoiado pelo então governador José Reinaldo Tavares, que tinha rompido com os Sarneys durante o mandato.
} 
O deputado Sarney Filho reafirmou ontem em entrevista coletiva a devolução de sua candidatura ao partido, sob o argumento que não deseja penalizar seus companheiros de agremiação, pelo erro de haver sido, durante anos, o grande avalista da Aliança Democrática que conduziu o governador Epitácio Cafeteira ao governo do Estado, hoje rompido com o parlamentar (JORNAL O ESTADO DO MARANHÃO Apud GONÇALVES, 2008, p. 112-113).

A partir deste momento, segundo Maria de Fátima Gonçalves em $A$ invenção de uma rainha de espadas (2008), coube a Sarney Filho o papel de protetor político de sua irmã, Roseana Sarney, que candidata-se pela primeira a um cargo eletivo em 1990, buscando obter o mesmo cargo de seu irmão, deputado federal. Ambos disputam a eleição visando vaga na Câmara dos Deputados. Além disso, o político era o principal instrumento da família Sarney a ataques contra adversários, fossem através da mídia (Sistema Mirante de Comunicação, principalmente o jornal $O$ Estado do Maranhão) ou em reunião políticas, como comícios: "Sarney Filho se candidatou ao mesmo cargo que estava e se tornou uma espécie de vitrine blindada de onde saiam os torpedos jocosos e desqualificados para o candidato oposicionista ao governo do Maranhão, João Castelo" (GONÇALVES, 2008, p. 113).

Roseana Sarney Murad é a mais velha dos três filhos de José Sarney. Fez seus estudos fundamentais em São Luís (Escola Normal do Maranhão - Liceu) e Brasília (Colégio Sacré Coeur de Marie), onde concluiu o segundo grau no colégio pré-universitário. Possui graduação e Ciências Sociais pela Universidade de Brasília (UnB). Difere de seu irmão em dois aspectos relevantes do estudo: 1) possui vasta experiência na administração pública antes de candidatar-se pela primeira vez a um cargo eletivo; 2) Sarney Filho não é alvo de textos acadêmicos ${ }^{14}$, ao contrário de sua irmã, sempre citada como a herdeira do capital e herança política de seu pai. O texto que serve de fonte para a maioria das informações sobre Roseana Sarney é uma tese de doutorado sobre sua trajetória política, sendo a mesma a herdeira do projeto ${ }^{15}$ iniciado por seu pai na década de 1960. Em entrevista concedida ao jornal de propriedade de seu irmão, afirma que entrou na política por "vocação":

\footnotetext{
${ }^{14}$ Apesar da grande quantidade de textos que explanem sobre a política maranhense no século XX e XXI, o único que encontramos algo sobre Sarney Filho é o de Gonçalves (2008), onde o alvo central é Roseana Sarney. Seu irmão é citado de forma tímida na produção.

${ }^{15}$ Tal projeto também é alvo de estudo de Maria de Fátima Gonçalves, A reinvenção do Maranhão Dinástico (2000), onde, segundo a autora, José Sarney busca uma ruptura com a forma como o estado era gerido, mas reforça tal forma de se administrar, através dos laços pessoais para a escolha de seus membros, ou seja, construiu um "campo burocrático marcado pela pessoalidade das relações, pelas escolhas sustentadas nos laços de consanguíneos e de parentesco por aliança" (2008, 70-71).
} 
Desde o meu tempo de estudante nunca fiquei indiferente, sempre fui engajada. No Liceu fui eleita secretária do grêmio estudantil; com apenas $\mathbf{1 2}$ anos de idade já participava da campanha de José Sarney para o governo do Maranhão. Evidentemente a vivência familiar contribuiu para o desabrochar dessa vocação [...] sempre quis ter meu espaço político próprio, e só poderia me apresentar ao eleitorado com o que tivesse pessoalmente em matéria de vivências. Acumulei uma certa experiência e pude participar do debate de grandes temas nacionais, com visão crítica e opinião pessoal sobre economia, política, sobre pobreza, as injustiças sociais, o sofrimento do povo (JORNAL O ESTADO DO MARANHÃO Apud GONÇALVES, 2008, p. 133. Grifos meus)

A passagem mostra diversas nuances da trajetória de Roseana Sarney, uma vez que ela aciona múltiplos vínculos e trunfos para justificar sua entrada na vida política em início da década de 1990. A participação em campanhas desde cedo não é novidade na vida de crianças criadas em seios políticos, onde parentes participam desse universo, com afirma Letícia Canêdo ${ }^{16}$ (1991). Com relação a sua "visão crítica", a mesma faz referência à sua formação em Ciências Sociais, que foi usada como trunfo de campanha em 1990, quando em diversos artigos em O Estado do Maranhão aparece o termo "socióloga" para apresentar a então candidata a deputada federal: "uma recepção que atestou o prestígio da candidata no sertão maranhense foi oferecida à socióloga Roseana Sarney na sua visita a Caxias". Como diz Gonçalves, acionar seu capital escolar coloca a candidata enquanto diferente de seus rivais, além de ter seu próprio trunfo no processo de criação ${ }^{17}$ da sua imagem como política: "ser 'socióloga' também remete a chamada 'opinião pública' para outros atributos ligados a estes: estudiosa, intelectual, conhecedora profunda de problemas sociais abrangentes. É assim um capital intelectual que naquele momento fornece peso significativo ao campo dos atributos utilizados na competição política" (2008, p. 120).

\footnotetext{
16 "A criança desde cedo vê desfilar em casa os mais diversos visitantes, de políticos a solicitadores, denominados 'protegidos' da família. Faz parte da sua vida particular dos acontecimentos sociais locais, nos quais percebe os olhares dos presentes sobre o seu grupo familiar. Cumprimentar convidados, parentes e amigos, aprender a sorrir, deixar brinquedos e frequentar festas de casamentos na roça, escutar distraidamente conversações de políticos, acompanhar o trabalho entre os eleitores e a 'elevação da temperatura' na vida familiar às vésperas das eleições, perceber os pequenos cuidados necessários para dominar os detalhes do jogo básico do homem político, tudo isso faz parte da conduta regular de uma criança e representa a forma de capital mais importante dentre todas as que constituem investimento para o sucesso na carreira política" (CANÊDO, 1991, p. 232).
}

17 Após essa eleição, não há referência de Roseana Sarney acionando sua condição de socióloga durante campanhas eleitorais. 
Já sobre sua "certa experiência", Roseana Sarney leva em consideração os cargos ocupados antes de se lançar como candidata ${ }^{18}$. Em seu currículo profissional encontram-se cinco cargos de assessoria: Companhia Urbanizadora da Nova Capital do Brasil (1974 a 1976), Secretaria de Viação e Obras $^{19}$ (1977 a 1978), Gabinete Civil do governador do Maranhão (1981, mandato de João Castelo), Senado Federal (1985) e Gabinete Civil da Presidência da República (1985 a 1989, mandato de José Sarney). Além do cargo de assessora (não há especificações da natureza da assessoria), foi técnica em planejamento e coordenadora do programa nacional de centros sociais urbanos, ambos exercidos no Instituto de Planejamento Econômico e Social, IPEA, em 1979 e 1980 respectivamente, além de secretária para assuntos extraordinários do Maranhão entre 1983 e 1984 no mandato de Luiz Rocha como governador do estado.

É com esse conjunto de capitais que Roseana Sarney se candidato pela primeira vez em 1990 ao cargo de deputada federal. Seu irmão concorreu ao mesmo cargo naquele e ambos saíram vitorioso. Vale lembrar que Sarney Filho inicia sua trajetória política como deputado estadual. Ambos começam "por cima", ou seja, em cargo alto na esfera política. Essa característica é observada por Grill (2008) ${ }^{20}$ como um padrão da política maranhense, onde diversos herdeiros de patrimônios políticos familiares têm como primeiro cargo a legislatura em nível estadual ou federal, não passando por cargos executivos municipais ou pela vereança. Teve apenas duas filiações partidária em sua trajetória: PFL entre 1990 e 2006 e PMDB. Interessante notar que Roseana Sarney e Sarney Filho estiveram no mesmo partido que seu pai por breves momentos após a redemocratização, cada um sendo filiado a um partido diferente, sendo seus líderes em nível estadual. O controle dessas instituições é um ponto que pode ser elencado como elemento explicativo para da hegemonia da família Sarney no Maranhão.

\footnotetext{
${ }^{18}$ André Marenco em $O$ que podemos explicar estudando carreiras políticas? (2013), cita Gaxie e Offerlé, que afirmam que "o homem político se destaca pela carreira estável e o treinamento constituído ao longo da trajetória percorrida entre postos públicos e a organização partidária que permitem a aquisição de um saber fazer organizacional e a aprendizagem de tecnologias indispensáveis ao exercício do trabalho político: domínio da fala, redação de discursos, domínio de técnicas de controle e manipulação de assembleias, acostumar-se a discussão com responsáveis administrativos ou políticos... e o enraizamento de um sentimento de competência política" (2013, p. 46).

${ }^{19}$ Seus dois primeiros cargos foram em instituições que tinham José Reinaldo Tavares com algum cargo de chefia, superintendente e secretário, respectivamente.

${ }^{20}$ Segundo pesquisa feita pelo autor com os deputados federais eleitos pelo Maranhão entre 1945 e 2006 , $80 \%$ tiveram como primeiro posto político o cargo de deputado estadual ou federal (GRILL, 2008b, p. 39).
} 
Após a eleição para a Câmara dos Deputados, Roseana Sarney é eleita governadora do Maranhão em 1994 (a primeira mulher eleita para o cargo de governador no Brasil) e reeleita em 1998. Ao deixar o cargo, candidata-se e vence a eleição para o Senado Federal em 2002. Concorre novamente a governadora em 2006, perdendo para Jackson Lago que, após ser cassado, deixa o cargo, assumido pela candidata derrotada, que se reelege em 2010. Assim, foram quatro mandatos como governadora do Maranhão. De 1995 até 2014, o único período que ela não exerceu o mais alto cargo do executivo maranhense foi entre os anos de 2003 e 2009.

Suas duas primeiras eleições foram as que contaram de forma mais enfática com o apoio de membros de sua família. Em 1990, Sarney Filho adotou o papel de protetor da irmã, que se lançava na arena política pela primeira, enquanto ele já tinha mais de uma década de experiências nesse tipo de jogo. Segundo Gonçalves, Sarney Filho "instituiu-se como um escudo às prováveis suscetibilidades e fragilidades políticas da irmã, iniciante no jogo político regional, Roseana Sarney Murad" (GONÇALVES, 2008, p. 113). Roseana Sarney foi a candidata mais votada do Maranhão para o cargo de deputado federal, ficando seu irmão com a quinta colocação no computo geral. Já em 1994, em uma eleição mais disputada, para o cargo de governador, contra um ex-aliado e exgovernador, Epitácio Cafeteira, em muitos momentos a presença de seu pai foi necessária, principalmente no segundo turno, uma vez que não era esperada a necessidade de mais um turno para a definição. Em 1998 José Sarney também participa ativamente do processo eleitoral, uma vez que a saúde da candidata estava debilitada. Assim, seu pai assume o papel de principal cabo eleitoral, indo a comício e reuniões pelo interior. Nos dizeres de Gonçalves, "quando a candidata à reeleição está fisicamente impossibilitada de se fazer presente fisicamente em diversos lugares bairros, municípios, povoados - nos espaços de sociabilidade política, José Sarney a representa, representando a si mesmo" (2008, p. 154).

Um dos principais trunfos das campanhas de Roseana Sarney foi o acesso à rede de relações instaurada por seu pai ao longo de sua vida pública e mantida pelo mesmo e por outros membros, fossem eles parentes consanguíneos ou simbólicos. Para tanto, o interior do estado era terreno fértil para a então candidata prosperar. A "itinerância" pelos municípios maranhenses em suas campanhas era uma das estratégias que Gonçalves (2008) destaca sobre o processo de "fabricação" de Roseana Sarney como um ser político. Uma vez que boa parte dos municípios maranhense tinha como principais lideranças políticas naquele momento aliados da família Sarney, as visitas a localidades no interior atendiam a um duplo interesse: de um lado estava a 
candidata buscando os votos da região; do outro, os políticos locais tentando reforçar os laços com a família Sarney. Dessa forma, segundo o jornal O estado do Maranhão, a popularidade da filha de José Sarney trouxe um "problema" para a mesma:

\begin{abstract}
A candidata à deputada federal Roseana Sarney está às voltas com um problema sui generis na atual campanha eleitoral. Enquanto a maioria dos candidatos tenta, por todos os meios conseguir apoio dos prefeitos, ex-prefeitos, vereadores e candidatos à Assembleia, Roseana tenta administrar o volume de adesões voluntárias que estão chegando ao seu comitê político. Como seu nome é de facílima penetração no eleitorado, é natural a corrida ao seu comitê, pois os que a apoiarem terminarão também sendo beneficiados (JORNAL O ESTADO DO MARANHÃO Apud GONÇALVES, 2008, p. 125-126).
\end{abstract}

Vale destacar na trajetória de Roseana Sarney sua união matrimonial com o empresário Jorge Francisco Murad, membro de uma família de libaneses que se destacou no ramo comercial, assim como algumas outras durante o século XX no Maranhão, como Duailibe, Haickel, Ayoub, etc $^{21}$. Outro membro da família Murad também tem relação direta com os Sarneys através de laços matrimoniais ${ }^{22}$. Teresa Murad é casada com Fernando Sarney, irmão de Roseana Sarney. Os Murad são oriundos da cidade de Coroatá, sendo considerados uma "família de empresários", atuando no comércio varejista. Alguns de seus membros reconvertem seu poderio econômico em postos políticos, tendo eles exercido diversos cargos públicos, como Emílio Murad ${ }^{23}$, que foi vereador, deputado estadual e federal, secretário de desporto e lazer do Maranhão, todos os cargos exercidos entre as décadas de 1960 e 1980; Ricardo Murad, sobrinho de Emílio Murad, formado em Direito pela Universidade Federal do Maranhão, foi prefeito de Coroatá, deputado estadual em quatro oportunidades, deputado federal por um mandato, além de ter sido gerente da região metropolitana de São Luís entre 2003 e 2004, bem como secretário de saúde do estado no mandato de Roseana Sarney entre 2009 e 2014. Sua esposa atualmente é prefeita de Coroatá. A filha do casal, Andrea Murad, é deputada estadual eleita em 2014 pela primeira vez a um cargo eletivo.

\footnotetext{
${ }^{21}$ Para mais detalhes sobre famílias de libaneses no Maranhão e a reconversão de capitais, ver Grill (2009).

${ }^{22}$ Em estudo acerca de famílias de políticos em Minas Gerais, Canêdo (1991) destaca casamentos como forma de acúmulo de capital político, afirmando que o enlace não é aleatório, mas sim uma estratégia que visa dividendos políticos.

${ }^{23}$ Ingrid Assis trabalhou em dissertação de mestrado os descendentes de libaneses e suas atuações nas esferas econômica e política no Maranhão (2012).
} 


\section{A TERCEIRA GERAÇÃO E A TRANSMISSÃO DO LEGADO AO NETO: ADRIANO SARNEY}

Nas eleições de 2014, dois membros da família Sarney lançaram-se no pleito buscando eleição para os cargos de deputado federal e estadual: José Sarney Filho e seu filho, Adriano Sarney. Desde a eleição de José Sarney ao governo do Maranhão em 1965, quatro membros da família exerceram cargos públicos que precisaram da legitimação popular. Além do próprio, dois de seus filhos venceram eleições (citados anteriormente). O último a aventurar-se na esfera política foi Adriano Sarney.

Nascido em São Luís, tinha 34 à época da campanha, é formado em administração de empresas e economia. Casado, concorreu ao cargo de deputado estadual pelo Partido Verde ${ }^{24}$, onde ainda se encontra filiado. Essa foi sua primeira experiência como pleiteante de um cargo público. Seu nome esteve envolvido na disputa para a prefeitura de Paço do Lumiar em 2012, município da região metropolitana de São Luís, porém, não se confirmou. Segundo informações disponibilizadas pelo agente ao Tribunal Superior Eleitoral, o patrimônio do então candidato era de mais de $\mathrm{R} \$ 1,8$ milhão, distribuídos entre imóveis (residenciais e comerciais), automóveis e investimentos bancários (aplicações, fundos de investimento, poupança, etc.).

Em 2014, fez dobradinha com seu pai, o que Ihe possibilitou acesso a toda rede de relações de sua família, o que fica claro nas inserções do Horário Eleitoral Gratuito (HEG). Alguns prefeitos aliados à família Sarney declararam apoio a Adriano Sarney em vídeo, como o prefeito de ApicumAçu, cidade localizada no litoral ocidental maranhense (distante aproximadamente $530 \mathrm{~km}$ da capital São Luís), bem como a ex-prefeita de São Luís entre 1993 e 1996, Conceição Andrade, que destacou: "Vale a pena sim votar no Adriano Sarney, que é uma pessoa de uma família política tradicional e séria desse Estado" (Horário Eleitoral Gratuito de Adriano Sarney). A passagem aciona o pertencimento do agente à principal família de políticos do Estado. Diferente de casos em que candidatos ocultam o sobrenome de sua família em disputas para não fazer essa associação direta, muitas vezes por algum membro ter tido problemas que maculassem a honra de todos os membros, Adriano Sarney não esconde seu sobrenome, pelo contrário, usa-o para relacionar seu nome à família, principalmente a seu avô, José Sarney.

\footnotetext{
${ }^{24}$ Durante o período de campanha, Adriano Sarney exercia o cargo de coordenador metropolitano do Partido Verde em São Luís.
} 
Durante o HEG, o candidato usou o mote recorrente a vários políticos de sua faixa etária, a juventude. Em diversas situações o candidato aparece junto a pessoas jovens, bem como possíveis eleitores fazendo referência à renovação política. Nos seus programas, que duravam entre trinta segundos e um minuto e meio ${ }^{25}$, Adriano Sarney tinha como principal frase "Não sou mais um, sou um a mais". A mesma pode ter diversas interpretações, porém, levando em conta o espaço social maranhense, refere-se principalmente ao agente ser membro da família Sarney. Pelo motivo acima citado, do uso do sobrenome, o candidato coloca-se no jogo político não como mais um Sarney. Vale lembrar que, normalmente, os membros da família Sarney sofrem ataques dos ataques de seus adversários políticos de forma constante. Com o candidato a deputado estadual não foi diferente. Frequentemente os rivais dizem que ele era mais um Sarney no jogo político local, daí a frase mote de sua campanha.

No mote percebe-se, como foi dito, que o agente tenta se desvencilhar do estigma de ser mais um Sarney, mesmo que tenha adotado o sobrenome de sua família no material de campanha. É um comum políticos que tem o nome de sua família desgastados na esfera política ocultarem o nome da mesma durante a campanha. O nome Sarney acaba sendo uma faca de dois gumes para o então candidato: de um lado, aciona o capital político de sua família, ainda forte no contexto estadual, por outro, precisa trabalhar com a alta rejeição do seu sobrenome, principalmente na capital e nas grandes cidades.

Um dos principais locais de campanha de Adriano Sarney foi a capital, São Luís, mais especificamente os bairros periféricos. No HEG, o bairro Cidade Olímpica aparece diversas vezes. A região pobre de São Luís tem aproximadamente 150 mil pessoas, sendo escolhida pelo candidato pela grande quantidade de problemas sociais e alta densidade demográfica, aliada ao fato que o então candidato a governador Flávio Dino era aliado do prefeito de São Luís, Edivaldo Holanda Jr, que era fortemente criticado durante a campanha. É nesse espaço de fortes críticas que Adriano Sarney entra para fazer campanha em bairros de São Luís.

Voltando à questão do acionamento do capital político de sua família durante a campanha, Adriano Sarney afirma em um programa do HEG que "a política para mim é muito mais do que

\footnotetext{
$25 \mathrm{O}$ fato de ser um dos principais nomes do partido no Maranhão o fez ter a possibilidade de que seu programa tivesse bastante tempo na televisão. Os outros candidatos do partido tinham em média trinta segundos a sua disposição no HEG.
} 
vocação, é destino. Aprendi desde cedo que por meio dela podemos ajudar as pessoas, contribuir com o desenvolvimento do nosso Estado". Como citado anteriormente, diversos autores abordam a questão da transmissão do patrimônio político a herdeiros. No caso de Adriano Sarney, quem o faz é seu avô, José Sarney, que aparece em dois programas do HEG do candidato. Seguem as falas de apoio do então senador da república pelo Amapá ao seu neto:

Estou aqui como avô para conversar com você sobre o Adriano. Ele é o meu primeiro neto homem. Ele é economista, administrador e sempre foi muito estudioso. Eu fiquei surpreso com a sua decisão de entrar na política e confesso: senti, no fundo, um imenso orgulho de ver meu neto desejar colocar seus conhecimentos à serviço de sua terra que ele tanto ama. Eu acredito que Adriano tem muito a oferecer para o Maranhão, com seu conhecimento, a sua juventude e sua determinação de fazer sempre o melhor (Horário Eleitoral Gratuito de Adriano Sarney, 2014).

Adriano Sarney é meu primeiro neto homem e vocês sabem que neto é uma coisa muito séria. Eu o considero muito preparado e quero conversar com você sobre ele. Adriano não me pediu, mas eu me senti no dever de dar esse testemunho. Com a minha responsabilidade política que vocês todos conhecem, eu não viria aqui apenas pela corujice de um avô, mas fiquei muito surpreso e orgulhoso quando ele me disse que desejava ser político por vocação e sua paixão pelo Maranhão nunca tinha saído da sua cabeça. Eu vi então um jovem nunca esquecer a sua terra e querer colocar a serviço dela todo conhecimento que ele adquiriu. Tenho certeza que com a mesma responsabilidade que ele teve como bom estudante, ele terá na escolha que fez. Na Assembleia Legislativa, Adriano Sarney com seu conhecimento poderá muito contribuir para o Maranhão e será um político muito responsável (Horário Eleitoral Gratuito de Adriano Sarney, 2014).

Alguns pontos são recorrentes nas falas de José Sarney. A juventude e a formação superior são destacadas, reforçando a ideia que o candidato já vinha adotando na campanha, de dialogar com um público que esperava a renovação dos quadros políticos, bem como a preparação para ocupação de um cargo público. Os cursos de formação são citados, para reforçar que o mesmo está realmente preparado e é conhecedor dos problemas que o espera. Outro ponto que chama a atenção é o orgulho que José Sarney tem de ver seu "primeiro neto homem" lançar-se em pleitos políticos. O então candidato foi eleito com 48.463 votos, segunda maior votação do Partido Verde, sendo o décimo terceiro mais votado no estado. Convém destacar que o PV estava coligado com o PMDB (partido da então governadora Roseana Sarney e do candidato que tinha seu apoio, Edison 
Lobão Filho, filho do ex-governador Edison Lobão. O candidato teve seus votos distribuídos em 187 municípios do Maranhão (de um total de 217).

\section{CONSIDERAÇÕES FINAIS}

Durante um período de meio século, a família Sarney, através de seus membros, comandou as ações políticas no Maranhão de forma sistemática. Para tanto, foi fundamental as articulações que os mesmos tinham "para cima", ou seja, com o poder central, e "para baixo", com os municípios. A cada dois anos, os laços eram reforçados, sendo José Sarney no senado, Sarney Filho na câmara dos deputados e Roseana Sarney no Palácios dos Leões, figuras fundamentais para a busca de líderes que apoiassem as empreitadas de pleiteantes a prefeituras. O apoio era "pago" de diversas maneiras, sendo a principal delas o retorno no apoio dos prefeitos eleitos aos membros da família Sarney a cargos mais altos. Além disso, retribuições em forma de doação de concessões de radiodifusão eram comuns, principalmente quando José Sarney foi presidente da república na segunda metade da década de 1980. Os políticos que por ventura perdessem as disputas nos municípios ainda eram agraciados com cargos na administração estadual, através de secretarias (titulares ou adjuntas) no período estudado. Some-se a isso o controle sobre a Assembleia Legislativa, uma vez que a grande maioria dos deputados eram eleitos com o apoios dos Sarneys ou então "migravam" da oposição para a situação após o pleito, e o monopólio dos meios de comunicação no estado, sendo os dois maiores sistemas de informação de posse dos mesmos e da família Lobão, aliada de longa data. Os pontos acima dão em boa medida uma ideia geral das formas de controle que a família Sarney teve de um estado nordestino por cinquenta anos. 


\section{REFERÊNCIAS}

ABÉLÈS, Marc. La reference familiale. In: L’hérédité en politique. PATRIAT, C.; PARODI, J. (Orgs.). Paris: Economica, 1992.

ARRUDA, César Viega. "Coronelismo eletrônico?" - a construção política do Grupo Sarney e o uso do aparelhamento da mídia no Maranhão. In: Ciências Humanas em Revista, v 5, São Luís, 2007.

ASSIS, Ingrid Pereira de. Descendentes de libaneses na política do Maranhão: ascensão econômica, relações pessoais e afirmação política. Dissertação de mestrado, UFMA, 2012.

BORGES, Arleth. PT Maranhão 1980-1992: origens, organização e governos municipais. EDUFMA, São Luís, 2008.

BOURDIEU, Pierre. Stratégies de reproduction et modes de domination. In: Actes de la recherche en sciences sociales. № 105, Paris, 1994.

BOURDIEU, Pierre; PASSERON, Jean-Claude. Os herdeiros: os estudantes e a cultura. Editora da UFSC, Florianópolis, 2014.

BUZAR, Benedito. Vitorinistas e oposicionistas (biografias). Editora Lithograf, São Luís, 2001.

BUZAR, Benedito. O vitorinismo: lutas políticas no Maranhão de 1945 a 1965. Instituto Geia, São Luís, 2014.

CANÊDO, Letícia. Estratégias familiares na produção social de uma qualificação política. In: Educação e Sociedade. № 39, Ano XII, 1991.

CARVALHO, José Murilo de. Mandonismo, Coronelismo, Clientelismo: uma discussão conceitual. In: Dados. v.40, n.2, Rio de Janeiro, 1997.

COSTA, Wagner Cabral da. Do "Maranhão Novo" ao "Novo Tempo": trajetória da oligarquia Sarney no Maranhão. São Luís, UFMA, (1997).

COSTA, Wagner Cabral da. Sob o signo da morte: o poder oligárquico de Victorino a Sarney. EDUFMA, São Luís, 2006. 
COUTO, Carlos Agostinho. Estado, mídia e oligarquia: poder público e meios de comunicação como suporte de um projeto político para o Maranhão. EDUFMA, São Luís, 2009.

FREIRE, Vitorino. A laje da Raposa. Rio de Janeiro: Guavira, 1978.

GONÇALVES, Maria de Fátima da Costa. A reinvenção do Maranhão dinástico. São Luís: Edições UFMA/PROIN (CS), 2000.

GRILL, Igor Gastal. As bases sociais da especialização política no Rio Grande do Sul e no Maranhão. In: GRILL, Igor. (Org.). Elites, profissionais e lideranças políticas (RS e MA): pesquisas recentes. EDUFMA, São Luís, 2008.

GRILL, Igor. Ismos, Ícones e Intérpretes - as lógicas das etiquetagens na política de dois estados brasileiros (MA e RS). In: Revista de Sociologia e Política. V 20, № 43, Curitiba, 2012.

HEREDIA, Beatriz. Lutas entre iguais: as disputas no interior de uma facção política. In: PALMEIRA, Moacir; BARREIRA, César. (Orgs.). Política no Brasil: visões de antropólogos. Rio de Janeiro: Relume Dumará: Núcleo de Antropologia da Política, 2006.

LEAL, Victor Nunes. Coronelismo, enxada e voto: o município e o regime representativo no Brasil. 4a edição. Editora Nova Fronteira, Rio de Janeiro, 1997

MARENCO, André. O que podemos explicar estudando carreiras políticas?. In: MARENCO, André (Org.). Os eleitos: representação e carreiras políticas em democracia. Editora da UFRGS, Porto Alegre, 2013.

MUXEL-DOUAIRE, Anne. Une histoire exemplaire: obstinations et nouveauté dans la transmition d'une traditions politique familiale. In: Pouvoirs, n.․ 42, 1987.

PACHÊCO FILHO, Alan Kardec Gomes. A construção midiática do político José Sarney: 1962-1970. Dissertação (Mestrado em História) - Universidade Federal de Pernambuco. UFPE, 2001.

PINÇON, Michel; PINÇON-CHARLOT, Monique. Sociologia da alta burguesia. In: Sociologias. n. 18, 2007.

QUEIROZ, Maria Isaura Pereira de. O mandonismo local na vida política brasileira. São Paulo, 1969. 